\title{
Part-per-trillion level detection of estradiol by competitive fluorescence immunoassay using DNA/dye conjugate as antibody multiple labels
}

\author{
Shengchao Zhu, Qin Zhang, Liang-Hong Guo* \\ State Key Laboratory of Environmental Chemistry and Ecotoxicology, Research Center for Eco-environmental Sciences, \\ Chinese Academy of Sciences, 18 Shuangqing Road, P.O. Box 2871, Beijing 100085, China
}

\section{A R T I C L E I N F O}

\section{Article history:}

Received 21 February 2008

Received in revised form

15 June 2008

Accepted 18 June 2008

Published on line 26 June 2008

\section{Keywords:}

Estradiol

Competitive immunoassay

Fluorescence

DNA/dye label

\begin{abstract}
A B S T R A C T
Fluorescent organic dyes are currently the standard signal-generating labels used in microarray quantification. However, new labeling strategies are needed to meet the demand for high sensitivity in the detection of low-abundance proteins and small molecules. In this report, a long-chain DNA/dye conjugate was used to attach multiple fluorescence labels on antibodies to improve signal intensity and immunoassay sensitivity. Compared with the 30 base-pair (bp) oligonucleotide used in our previous work [Q. Zhang, L.-H. Guo, Bioconjugate Chem. 18 (2007) 1668-1672], conjugation of a 219 bp DNA in solution with a fluorescent DNA binder SYBR Green I resulted in more than sixfold increase in signal intensity, consistent with the increase in bp number. In a direct immunoassay for the detection of goat anti-mouse IgG in a mouse IgG-coated 96-well plate, the long DNA conjugate label also produced higher fluorescence than the short one, accompanied by about 15-fold improvement in the detection limit. To demonstrate its advantage in real applications, the DNA/dye conjugate was employed in the competitive immunoassay of $17 \beta$-estradiol, a clinically and environmentally important analyte. The biotin-terminated DNA was attached to biotinylated anti-estradiol antibody through the biotin/streptavidin/biotin bridge after the immuno-reaction was completed, followed by conjugation with SYBR Green I. The limit of detection for $17 \beta$-estradiol is $1.9 \mathrm{pg} \mathrm{mL}^{-1}$, which is 200 -fold lower than the assay using fluorescein-labeled antibodies. The new multiple labeling strategy uses readily available reagents, and is also compatible with current biochip platform. It has great potential in the sensitive detection of protein and antibody microarrays.
\end{abstract}

(c) 2008 Elsevier B.V. All rights reserved.

\section{Introduction}

Due to their low cost, simplicity, versatility and relatively high specificity, immunoassays are widely used in life science research, drug discovery, clinical diagnostics and environmental monitoring [1,2]. Since radioisotope-labeled immunoassays were first introduced [3] in 1959, a vari- ety of labels have been developed [4], including fluorescent dyes and metal complexes [5], enzymes for colorimetric [6], chemiluminescent [7] and electrochemical detection [8], and metal chelates for electrochemiluminescent quantitation [9]. Although chemiluminescence is one of the most sensitive among the commercialized technologies, fluorescence has gained tremendous popularity for its instrument robustness,

\footnotetext{
* Corresponding author. Tel.: +8610 62849685; fax: +861062849685.

E-mail address: LHGuo@rcees.ac.cn (L.-H. Guo). 
label stability and assay flexibility. Currently, the standard biochip detection platform employs Cy3 and Cy5 fluorescent dyes for biomolecular labeling and confocal laser scanners for signal readout [10].

$17 \beta$-Estradiol (E2) is monitored routinely in clinical laboratories for female infertility, ovarian function assessment, and tumor diagnosis. It is also one of the endocrine-disrupting chemicals frequently found in many aquatic environments. Therefore, E2 is a clinically and environmentally important analyte. Both competitive and non-competitive immunoassays for E2 have been developed, some of them with a detection limit at part-per-trillion level. For instance, Zhao et al. developed a competitive chemiluminescence immunoassay with a detection limit of $1.5 \mathrm{pg} \mathrm{mL}^{-1}$, using AMPPD-alkaline phosphatase system for signal generation, and biotin-streptavidin for signal amplification [11]. A dynamic range from 2.5 to $1600 \mathrm{pg} \mathrm{mL}^{-1}$ was obtained on a Log-Logit scale. Lamminmäki et al. reported a competitive fluorescence immunoassay with a Eu-chelate label, and obtained a detection limit of $8 \mathrm{pM}\left(2.2 \mathrm{pg} \mathrm{mL}^{-1}\right)$ [12]. Kokko et al. applied a time-resolved fluorescence immunoassay to detect E2 in a homogeneous non-competitive format, and achieved a detection limit of $18 \mathrm{pM}\left(4.9 \mathrm{pg} \mathrm{mL}^{-1}\right)$ in buffer [13]. More recently, Glass et al. compared three commercialized immunoassay techniques for E2, namely surface plasmon resonance, kinetic exclusion, and ELISA [14]. The lowest detectable concentration for E2 was obtained in the kinetic exclusion assays, which was between $2 \mathrm{pM}$ and $40 \mathrm{nM}$ depending on the antibodies used, with a measurable range of 2-3 orders of magnitude.

In the past decade or so, a substantial amount of work has been carried out to improve fluorescence immunoassay sensitivity so as to meet the demand in proteomics research and environmental monitoring. One popular strategy is signal amplification by attaching a large number of labels to one antibody molecule, with the hope that signal increase would lead to sensitivity improvement. The labels are linked to the antibody either at multiple sites of the molecule with only one label at each site, or at one site with a macromolecular carrier. Although the multiple-site linkage is easier to implement synthetically, the single site approach is preferred in order to minimize structural change of the antibody and maintain its immuno-activity. Organic dendrimers $[15,16]$ and proteins [17] have been used as carriers to attach multiple fluorescent dyes to an antibody at a single site, although synthesis and purification of the dye-conjugated macromolecules is a daunting task. Fluorescence signal amplification has also been achieved by using fluorophore-doped silica and latex beads as labels $[18,19]$. The particle contains a large number of dyes, and is therefore substantially more fluorescent than a single fluorophore. An elegant approach was proposed by Sano et al. in which nucleic acids were labeled on antibodies, and were amplified by PCR after the immuno-reaction [20]. It has been demonstrated that immunoassay sensitivity is improved by 100-10,000 folds by such immuno-PCR technique [21], although it adds substantial amount of time and reagent cost by employing gel electrophoresis, PCR-ELISA or real-time PCR for assay readout.

In our previous report [22], DNA/dye conjugates were proposed as multiple fluorescent labels for antibodies. In a model immunoassay for mouse IgG in a 96 -well plate, a 30 base-pair (bp) oligonucleotide was attached to goat anti-mouse antibody as a long-chain carrier to conjugate multiple fluorescent DNA binders. It was found that fluorescence signal was increased by eightfold over the fluorescein-labeled antibody, accompanied by 10 -fold improvement in the detection limit. At almost the same time, Benvin et al. synthesized some fascinating fluorescent DNA nanotags and demonstrated their applications in flow cytometry and confocal microscopy for tracking the reaction at the level of individual molecules [23]. In the current work, a longer DNA/dye conjugate with 219 bp was employed in the competitive immunoassay for a highly demanding analyte, E2. The work demonstrates that part-per-trillion level E2 can be detected by the new multiple labeling strategy which can be implemented readily in antibody microarray detection.

\section{Experimental}

\subsection{Materials}

Taq DNA polymerase, DNA marker DL 2000 and DNA fragment purification kit were purchased from Takara Biotech Co. (Dalian, China). Agarose and streptavidin were obtained from Promega (Madison, WI). Fluorescein isothiocyanate (FITC) was from Amresco (Solon, $\mathrm{OH}$ ), and SYBR Green I from Invitrogen (Carlsbad, CA). Biotinyl-N-hydroxysuccinimide, E2, 17 $\beta$-estradiol 6-(O-carboxymethyl) oxime: BSA (E2-BSA), estrone, estriol, ethinyl estradiol and diethylstilbestrol were from Sigma-Aldrich (St. Louis, MO). Monoclonal antibody against estradiol was from Fitzgerald (Concord, MA). Bovine serum albumin V, mouse IgG, and goat anti-mouse IgG were from Xinjingke Corp. (Beijing, China). A $30 \mathrm{bp}$ biotinylated double-stranded oligonucleotide was obtained by hybridizing two complementary single-stranded oligonucleotides purchased from Invitrogen Shanghai (Shanghai, China), as described before [22]. The two oligonucleotides are biotin-5'TTT TTT TTT GCG GGT AAC GTC AAT ATT AAC TTT ACT CCC-3' and 5'-GGG AGT AAA GTT AAT ATT GAC GTT ACC CGC-3', respectively. FITC labeled streptavidin and biotin-IgG were obtained as described before [22], the label ratios were 1.2 and 3.8 per protein, respectively. All buffers were prepared in high-purity water from a Millipore Milli-Q (Biocel) purification system.

\subsection{DNA synthesis}

The $219 \mathrm{bp}$ DNA was synthesized using PCR protocol. Staphylococcus aureus subsp. aureus MW2 DNA was amplified with primers 5'-biotin-GTGTCGTGAGATGTTGGGTT-3' (sense) and 5'-ACTTTATGGGATTTGCTTGA-3' (anti-sense). The primers were synthesized by Invitrogen (Shanghai, China). The PCR mixture $(50 \mu \mathrm{L})$ contained Taq polymerase (1.25 U), dNTP mixture (each at $0.2 \mathrm{mM}$ ), primers (each at $0.4 \mu \mathrm{M}$ ), template DNA ( $\sim 10 \mathrm{ng}), \mathrm{MgCl}_{2}(1.5 \mathrm{mM}), 10 \times$ PCR buffer $(5 \mu \mathrm{L})$. The reaction was performed in a Biometra T-Gradient thermocycler (Goettingen, Germany). PCR condition was as follows. Reaction mixture was generally denatured at $94^{\circ} \mathrm{C}$ for $3 \mathrm{~min}$, followed by 30 cycles of denaturation at $94^{\circ} \mathrm{C}$ for $30 \mathrm{~s}$, annealing at $56^{\circ} \mathrm{C}$ for $30 \mathrm{~s}$ and extension at $72^{\circ} \mathrm{C}$ for $1 \mathrm{~min}$. The final chain extension was made at $72^{\circ} \mathrm{C}$ for $3 \mathrm{~min}$. The cycler was then ramped 
to $4^{\circ} \mathrm{C}$ and held until sample analysis. The PCR products were loaded onto $1.2 \%$ agarose gel in TBE buffer ( $45 \mathrm{mM}$ Tris-borate, $1 \mathrm{mM}$ EDTA, pH 8.0), stained with $0.5 \mu \mathrm{g} \mathrm{mL}^{-1}$ ethidium bromide, and directly visualized under UV illumination after electrophoresis. Then the PCR products were purified with the DNA fragment purification kit.

\subsection{Direct immunoassay of goat anti-mouse IgG}

The following is an optimized immunoassay protocol for the detection of goat anti-mouse IgG in 96-well plates to compare the $30 \mathrm{bp}$ oligonucleotide and $219 \mathrm{bp}$ DNA/dye conjugate label. First, a white 96-well microplate was coated with $100 \mu \mathrm{L}$ mouse IgG $\left(30 \mu \mathrm{gmL}^{-1}\right.$ in $50 \mathrm{mM}$ carbonate buffer, $\mathrm{pH}$ 9.6) by incubating overnight at $4^{\circ} \mathrm{C}$. The plate was washed three times with $300 \mu \mathrm{L}$ washing buffer $(50 \mathrm{mM}$ Tris, $50 \mathrm{mM} \mathrm{NaCl}$, $0.1 \%$ Tween 20, pH 8.0). The plate was then blocked overnight at $4{ }^{\circ} \mathrm{C}$ with $300 \mu \mathrm{L}$ blocking buffer ( $1 \%$ BSA in PBS, pH 7.4), and washed again. In the second step, $100 \mu \mathrm{L}$ biotin-labeled goat anti-mouse IgG of various concentrations was added into the plate and incubated at $37^{\circ} \mathrm{C}$ for $2 \mathrm{~h}$ with shaking, then washed. In the third step, $100 \mu \mathrm{L}$ of $5 \mu \mathrm{g} \mathrm{mL}^{-1}$ streptavidin was added into the well and reacted at $37^{\circ} \mathrm{C}$ for $2 \mathrm{~h}$ with shaking, then washed. In the fourth step, biotin-labeled $30 \mathrm{bp}$ oligonucleotide or $219 \mathrm{bp}$ DNA was added and reacted at $37^{\circ} \mathrm{C}$ for $2 \mathrm{~h}$ with shaking, and washed again. Finally, SYBR Green I was added into the plate and incubated for $7 \mathrm{~min}$ at room temperature with shaking. After wash to remove unbound dyes, fluorescence intensity was measured on a PerkinElmer luminescence spectrometer (Waltham, MA) with $498 \mathrm{~nm}$ excitation, $525 \mathrm{~nm}$ emission, $5 \mathrm{~nm}$ slit width, and $515 \mathrm{~nm}$ cutoff filter.

\subsection{Competitive immunoassay of E2}

A white 96-well microplate was coated with $100 \mu \mathrm{L}$ E2-BSA $\left(10 \mu \mathrm{g} \mathrm{mL}^{-1}\right.$ in $50 \mathrm{mM}$ carbonate buffer, $\mathrm{pH}$ 9.6) by incubating overnight at $4^{\circ} \mathrm{C}$, and washed. The plate was then blocked overnight at $4^{\circ} \mathrm{C}$ with $300 \mu \mathrm{L}$ blocking buffer, and washed. In the second step, $50 \mu \mathrm{L}$ E2 of various concentrations and $50 \mu \mathrm{L}$ of $20 \mu \mathrm{g} \mathrm{mL}^{-1}$ biotinylated E2 antibody were added into the coated well and incubated at $37^{\circ} \mathrm{C}$ for $2 \mathrm{~h}$ with shaking, then washed. In the third step, $100 \mu \mathrm{L}$ of $5 \mu \mathrm{g} \mathrm{mL}^{-1}$ streptavidin was added into the well and reacted at $37^{\circ} \mathrm{C}$ for $2 \mathrm{~h}$ with shaking, then washed. In the fourth step, biotin-labeled $219 \mathrm{bp}$ DNA $(88 \mathrm{nM})$ was added and reacted at $37^{\circ} \mathrm{C}$ for $1 \mathrm{~h}$ with shaking, and washed again. Finally, SYBR Green I (574 nM) was added into the plate and incubated for $7 \mathrm{~min}$ at room temperature with shaking. After wash, fluorescence intensity was measured as described above. In the comparison experiment, FITC labeled streptavidin $\left(5 \mu \mathrm{g} \mathrm{mL}^{-1}\right)$ was added in the third step instead of the unlabeled protein. Fluorescence was measured with $495 \mathrm{~nm}$ excitation, $525 \mathrm{~nm}$ emission, $5 \mathrm{~nm}$ slit width, and $515 \mathrm{~nm}$ cutoff filter.

\subsection{Chemiluminescence immunoassay}

E2 chemiluminescence immunoassay kits were purchased from Beijing Chemclin Biotech Co. (Beijing, China). Assay protocol recommended by the manufacturer was followed. Briefly,

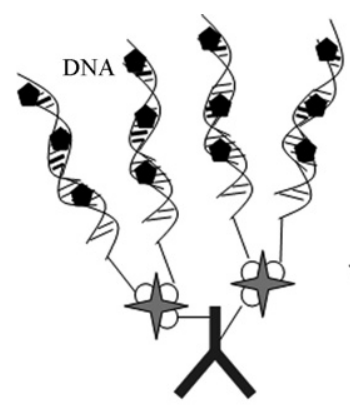

(a)

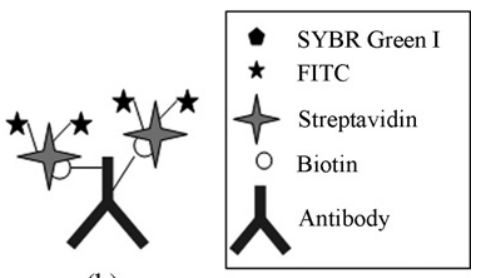

(b)
Scheme 1 - Illustration of the antibody multiple labeling strategy using a biotin-terminated DNA to carry a large number of fluorescent DNA binders SYBR Green I, and streptavidin to link the DNA to biotinylated antibody (a). Also illustrated in (b) is the conventional approach of using FITC-streptavidin to label the antibody.

$25 \mu \mathrm{L}$ E2 standard or sample solution, $100 \mu \mathrm{L}$ HRP-estradiol and $50 \mu \mathrm{L}$ estradiol antibody were added into a well of a 96well plate coated with a secondary antibody. After incubation for $90 \mathrm{~min}$ at $37^{\circ} \mathrm{C}$, the plate was washed five times, and $50 \mu \mathrm{L}$ chemiluminescence substrate solution was added. After 10 min incubation, light intensity was measured on a chemiluminescence microplate reader (BHP9504, Hamamatsu Co. Ltd., Beijing, China).

\section{Results and discussion}

As described in Section 1, our strategy is to use DNA as a macromolecular carrier to attach multiple fluorescent labels to an antibody at one site (Scheme 1). Our preliminary work with a 30 bp oligonucleotide/SYBR Green I label for mouse IgG has demonstrated the feasibility of the strategy [22]. Obviously, a longer DNA fragment would carry more fluorescent DNA binders than the short one, and consequently produce more fluorescence signal. However, it might also encounter more spatial hindrance during the immuno-complex formation on the microplate surface. In immuno-PCR experiments, DNA markers of 150-300 bp are commonly used [24]. Therefore, a $219 \mathrm{bp}$ DNA was synthesized in the current work to further increase the number of fluorescent labels in the DNA/dye conjugate so that the strategy could be implemented in real applications. The DNA had a randomly selected sequence, and was synthesized by PCR amplification. The gel image in Fig. 1 shows clearly that the PCR product is of high purity and correct length.

To characterize the binding interaction between SYBR Green I and long-chain DNA, the fluorescent probe was titrated into a solution of $5 \mathrm{nM}$ DNA at increasing concentrations. As illustrated in Fig. 2, the fluorescence intensity increased gradually from 0 to $0.25 \mu \mathrm{M}$ dye, then reached a plateau at higher concentrations. The observed dye/DNA molar binding ratio is about five times larger than the $30 \mathrm{bp}$ oligonucleotide. In addition, the fluorescence intensity at saturating dye concentration is approximately 6.5 higher, which correlates well with the increase in the number of base-pair (from 30 to $219 \mathrm{bp}$ ). 


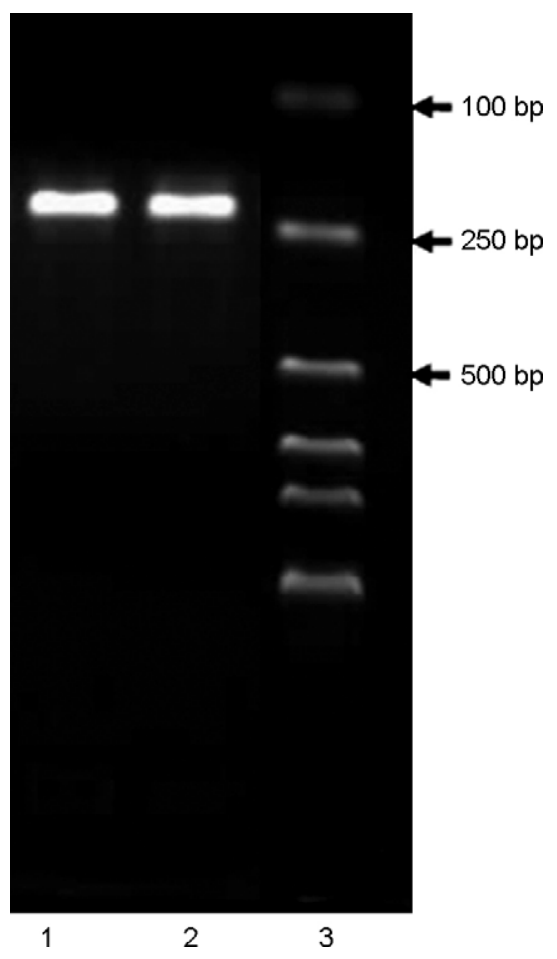

Fig. 1 - Electrophoresis gel image of DNA PCR product. Lane 1 and 2, PCR product; Lane 3, DNA marker DL 2000. The PCR product was loaded onto $1.2 \%$ agarose gel in TBE buffer (45 mM Tris-borate, 1 mM EDTA, pH 8.0), and stained with $0.5 \mu \mathrm{g} \mathrm{mL}^{-1}$ ethidium bromide.
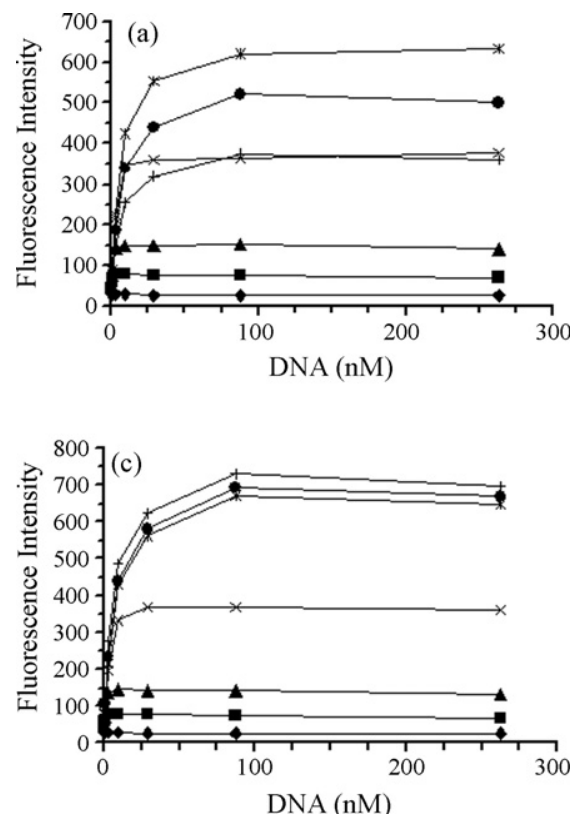

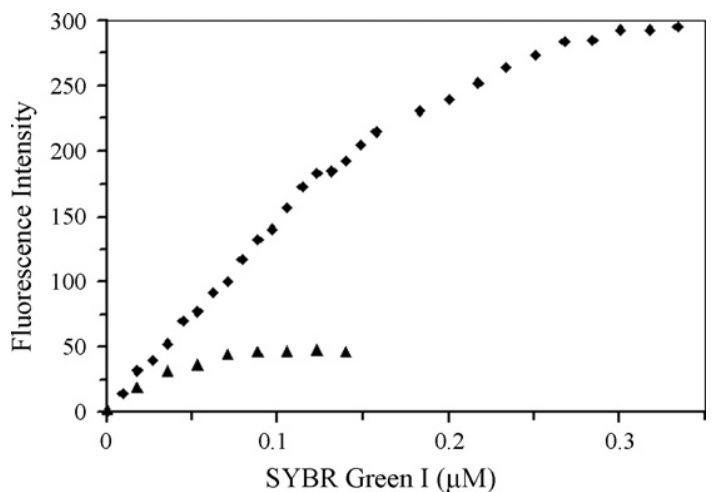

Fig. 2 - Fluorescence titration curve of SYBR Green I into $5 \mathrm{nM} 219 \mathrm{bp}$ DNA $(\downarrow)$ and $30 \mathrm{bp}$ oligonucleotide $(\Delta)$ in $50 \mathrm{mM}$ Tris/50 mM NaCl, pH 8.0. Fluorescence intensity was scanned with $498 \mathrm{~nm}$ excitation, $525 \mathrm{~nm}$ emission, $5 \mathrm{~nm}$ slit width.

After the characterization, a direct immunoassay for the detection of goat anti-mouse IgG was carried out in mouse IgG-coated 96-well plates to compare the signal intensity and detection limit of the two DNA/dye labels. The assay protocol described in Section 2 is the same as the one in our previous report. The optimal condition for the binding of the longchain DNA/SYBR Green I conjugate to the surface-attached IgG/biotinylated antibody (BT-Ab)/streptavidin (SA) immunocomplex was investigated also by following the previously published procedure. Based on the results depicted in Fig. 3, a combination of $88 \mathrm{nM}$ DNA and $574 \mathrm{nM}$ SYBR Green I produced the most intense signal in the washed measurement. In the assay for goat anti-mouse IgG, BT-Ab of various concen-
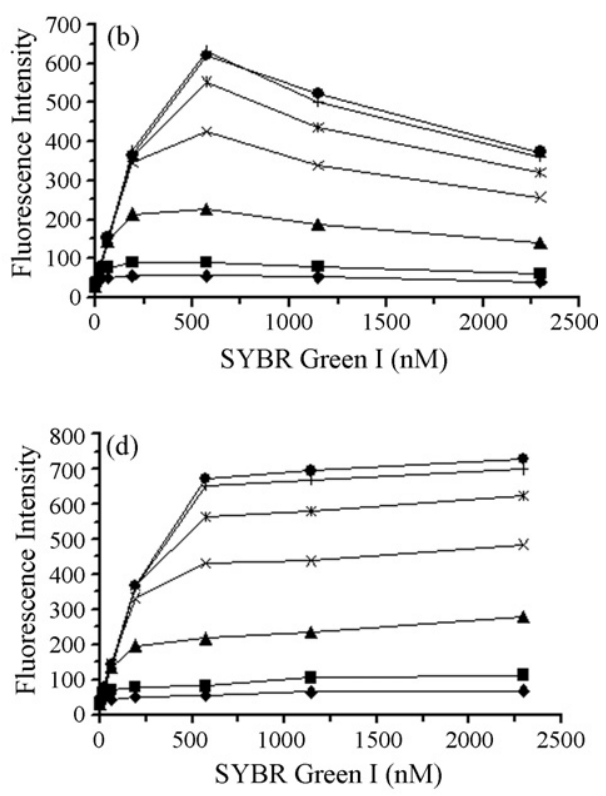

Fig. 3 - Fluorescence intensity of the long-chain DNA/SYBR Green I conjugate attached to the IgG/antibody/streptavidin complex formed on a 96-well plate as a function of DNA (a and c) and SYBR Green I (b and d) concentration. Different curves in (a) and (c) correspond to $0 \mathrm{nM}(\bullet), 21 \mathrm{nM}(\square), 64 \mathrm{nM}(\Delta), 191 \mathrm{nM}(\mathrm{x}), 574 \mathrm{nM}\left({ }^{*}\right), 1148 \mathrm{nM}(0)$, and $2296 \mathrm{nM}(+)$ SYBR Green I. Different curves in (b) and (d) correspond to $0.40 \mathrm{nM}(\bullet), 1.08 \mathrm{nM}(\square), 3.24 \mathrm{nM}(\Delta), 9.76 \mathrm{nM}(\times), 29.2 \mathrm{nM}\left({ }^{*}\right), 87.7 \mathrm{nM}(0)$, and $262.9 \mathrm{nM}(+)$ DNA. Fluorescence intensity was measured before (a and b) and after (c and d) plate wash. 


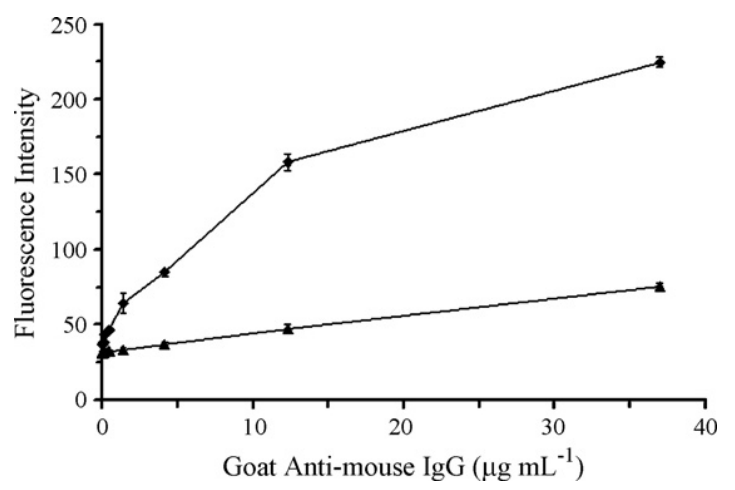

Fig. 4 - Fluorescence immunoassay for the detection of goat anti-mouse IgG on mouse IgG-coated 96-well plates, using the 219 bp DNA/SYBR Green I conjugate label ( $\downarrow)$, or the 30 bp oligonucleotide/SYBR Green I conjugate label ( $\Delta)$. Each data point is the average of three replicates.

trations was added to mouse IgG-coated plates, followed by streptavidin. Afterwards, $88 \mathrm{nM} 219 \mathrm{bp}$ DNA and $574 \mathrm{nM}$ SYBR Green I, or $1.22 \mu \mathrm{M} 30 \mathrm{bp}$ oligonucleotide and $255 \mathrm{nM}$ SYBR Green I, were added sequentially to the plate. As illustrated in Fig. 4, in both assays the fluorescence signal is progressively higher with increasing antibody concentration, suggesting that both DNA labels can be used for quantitative detection of immunoassays. However, in the whole range of antibody concentration examined, the signal of the long-chain DNA label is persistently higher than the short one by $3-4$ folds. The signal increase is not as much as what was observed in the solution titration experiment described above. This is likely due to the increased spatial hindrance of the long DNA molecule during its binding reaction with surface-bound streptavidin. The calculated limit of lower detection (3 times the standard deviation above the blank) is $0.12 \mu \mathrm{g} \mathrm{mL}^{-1}$ in the $219 \mathrm{bp}$ DNA-labeled assay and $1.77 \mu \mathrm{g} \mathrm{mL}^{-1}$ in the $30 \mathrm{bp}$ oligonucleotide-labeled assay, respectively. Obviously, the longer DNA label improved the detection sensitivity for goat anti-mouse IgG by 15-fold. This improvement comes in addition to the 10 -fold increase in sensitivity offered by the oligonucleotide label over the commonly used dye-labeled antibodies, as described in our previous work [22].

To demonstrate the superiority of the new labeling strategy in real applications, a competitive fluorescence immunoassay for E2 was performed, in which the $219 \mathrm{bp}$ DNA/dye conjugate labeled anti-E2 antibody and the commonly used fluorescein-labeled antibody were compared. In the assay, biotinylated anti-E2 antibody $\left(20 \mu \mathrm{g} \mathrm{mL}^{-1}\right)$ and E2 of various concentrations were added together into E2-BSA coated 96-well plates. In the dye-labeled assay, FITC-labeled streptavidin was then added to attach fluorescein dyes to the antibody, followed by the fluorescence measurement. In the conjugate-labeled assay, unlabeled streptavidin was added first, followed by the biotin-terminated $219 \mathrm{bp}$ DNA and SYBR Green I to attach multiple labels to the antibody. After wash, fluorescence was measured. Fig. 5 shows the results of the two competitive immunoassays for E2. From the competition curve, the measured limit of detection (the lowest E2 concentration tested in the assay which produced signal change
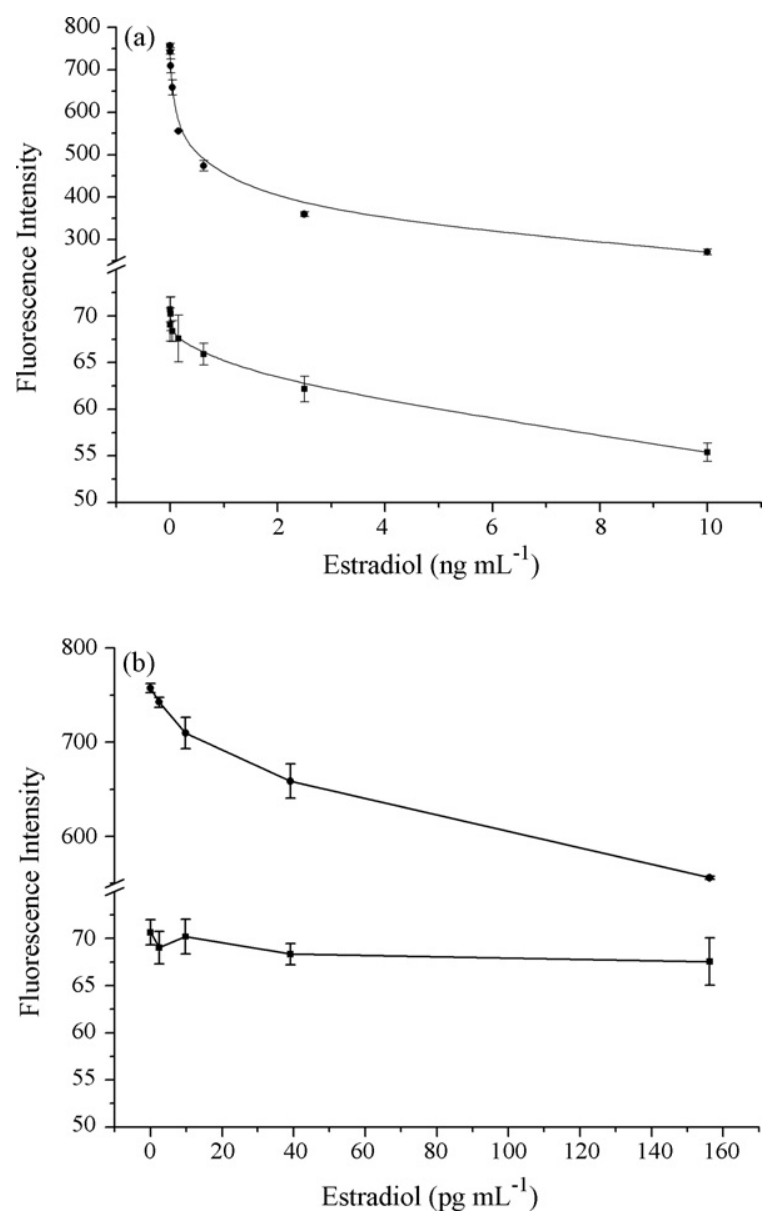

Fig. 5 - (a) Competitive fluorescence immunoassay for the detection of E2 on E2-BSA coated 96-well plates, using the SA/long chain DNA/dye conjugate labeled $(\Lambda)$ and FITC-SA labeled anti-E2 antibody ( $\square$ ). (b) An expanded view of (a) at low E2 concentrations. Each data point is the average of three replicates.

that is more than three times the standard deviation below the blank) is $2.4 \mathrm{pg} \mathrm{mL}^{-1}$ in the $\mathrm{DNA}$ /dye conjugate labeled assay, and $625 \mathrm{pg} \mathrm{mL}^{-1}$ in the fluorescein-labeled assay. The calculated LOD (which gives a signal equal to the zero signal minus three times the standard deviation of the zero signal) from the competition curve is $1.9 \mathrm{pg} \mathrm{mL}^{-1}(7 \mathrm{pM})$ and $421 \mathrm{pg} \mathrm{mL}^{-1}(1.55 \mathrm{nM})$, respectively. Apparently, the long-chain DNA/dye conjugate label improved the detection limit of E2 by over 200-fold. The highest E2 concentration measured in the experiment was $10,000 \mathrm{pg} \mathrm{mL}^{-1}$, which produced $70 \%$ signal inhibition. Thus, the working range of the assay spanned almost four orders of magnitude (Fig. 1S in the Supporting Materials).

To investigate the specificity of the assay, several E2 analogs were evaluated for their potential cross-reactivity with the E2 antibody. The cross-reactivity was calculated according to the equation:

Cross-reactivity $(\%)=\frac{\mathrm{IC}_{50} \text { of } \mathrm{E} 2}{\mathrm{IC}_{50} \text { of cross reactant }} \times 100 \%$ 
Table 1 - Immunoassay cross-reactivity of some chemical compounds structurally similar to estradiol

Chemicals Cross-reactivity (\%)

$17 \beta$-Estradiol 100 Estrone Estriol 0.2

Ethinyl estradiol 0.35 Diethylstilbestrol 0.9

Table 2 - Comparison between the concentration of prepared estradiol samples and that of reported by chemiluminescence immunoassay

\begin{tabular}{lrcc} 
Prepared $\left(\mathrm{pg} \mathrm{mL}^{-1}\right)$ & 39.06 & 156.25 & 625 \\
Reported $\left(\mathrm{pg} \mathrm{mL}^{-1}\right)$ & 38.96 & 151.29 & 618.07 \\
Deviation $(\%)$ & 0.25 & 3.3 & 1.1 \\
\hline
\end{tabular}

Table 1 shows the cross-reactivity of estrone, estriol, ethinyl estradiol and diethylstilbestrol. It is obvious from the table that the assay is highly specific for E2.

E2 sample solutions used in our fluorescence immunoassays were validated with commercial chemiluminescence microplate immunoassay kits. Since the measurable range of the kits is between 30 and $1000 \mathrm{pg} \mathrm{mL}^{-1}$, only three prepared E2 solutions $\left(39.06,156.25,625 \mathrm{pg} \mathrm{mL}^{-1}\right.$ ) were tested. As can be seen from Table 2, the reported concentration from the chemiluminescence tests agreed very well with the prepared concentration.

As described in Section 1, there are a few reports on the immunoassay detection of E2 with part-per-trillion level detection limit and 2-3 orders of magnitude measurable range [11-14]. The lower detection limit obtained in our assay (1.9 $\mathrm{pg} \mathrm{mL}^{-1}$ or $7 \mathrm{pM}$ ) is very similar to the chemiluminescence assay $\left(1.5 \mathrm{pg} \mathrm{mL}^{-1}\right)$, and only slightly inferior to the kinetic exclusion assay (2pM). But the present assay exhibited a significantly wider measurable range than the previous assays. One unique advantage of the DNA/dye labeled fluorescence immunoassay is that, because the signal-emitting molecules are immobile, it can be implemented in microarray detection. Although chemiluminescence is highly sensitive, it is not suitable for microarray detection. This is because the chemiluminescent compound diffuses freely in solution, and can cause crosstalk between discrete test sites. The kinetic exclusion assay [14] is performed on polymer beads, and therefore cannot be applied to microarrays. Protein and antibody microarray has become a very powerful tool in life science research. To detect low-abundance proteins and trace-level environmental pollutants and food contaminants on microarrays, it is very desirable to improve the microarray sensitivity. The DNA/dye labeled fluorescence immunoassay developed in this work, with its high sensitivity, wide working range, and compatibility with the current microarray fluorescence reader (in terms of excitation and emission wavelength), offers a very promising solution.

\section{Acknowledgements}

This work was supported by the National Basic Research Program of China (2006CB403303) and the National Natural Science Foundation of China (20621703).

\section{Appendix A. Supplementary data}

Supplementary data associated with this article can be found, in the online version, at doi:10.1016/j.aca.2008.06.028.

\section{REFERENCES}

[1] D.S. Hage, Anal. Chem. 71 (1999) 294R-304R.

[2] M. Vanderlaan, B.E. Watkins, L. Stanker, Environ. Sci. Technol. 22 (1988) 247-254.

[3] R.S. Yalow, S.A. Berson, Nature 184 (1959) 1648-1649.

[4] L.J. Kricka, Clin. Chem. 40 (1994) 347-357.

[5] J.R. Lakowicz, Topics in Fluorescence Spectroscopy, vol. 3: Biochemical Applications, Plenum Press, New York, 1992.

[6] C.A. Marquette, L.J. Blum, Biosens. Bioelectron. 21 (2006) 1424-1433.

[7] L.J. Kricka, Anal. Chem. 71 (1999) 305R-308R.

[8] A. Bange, H.B. Halsall, W.R. Heineman, Biosens. Bioelectron. 20 (2005) 2488-2503.

[9] G.F. Blackburn, H.P. Shah, J.H. Kenten, J. Leland, R.A. Kamin, J. Link, J. Peterman, M.J. Powell, A. Shah, D.B. Talley, Clin. Chem. 37 (1991) 1534-1539.

[10] M. Schena, Microarray Analysis, John Wiley \& Sons, Hoboken, 2003.

[11] L. Zhao, J.-M. Lin, Z. Li, X. Ying, Anal. Chim. Acta 558 (2006) 290-295.

[12] U. Lamminmäki, A. Westerlund-Karlsson, M. Toivola, P. Saviranta, Protein Sci. 12 (2003) 2549-2558.

[13] T. Kokko, L. Kokko, T. Lövgren, T. Soukka, Anal. Chem. 79 (2007) 5935-5940.

[14] T.R. Glass, N. Ohmura, H. Saiki, Anal. Chem. 79 (2007) 1954-1960.

[15] K.K. Ong, A.L. Jenkins, R. Cheng, D.A. Tomalia, H.D. Durst, J.L. Jensen, P.A. Emanuel, C.R. Swim, R. Yin, Anal. Chim. Acta 444 (2001) 143-148.

[16] M. Zhou, J. Roovers, G.P. Robertson, C.P. Grover, Anal. Chem. 75 (2003) 6708-6717.

[17] E.P. Diamandis, Clin. Chem. 37 (1991) 1486-1491.

[18] L. Wang, K. Wang, S. Santra, X. Zhao, L.R. Hilliard, J.E. Smith, Y. Wu, W. Tan, Anal. Chem. 78 (2006) 646-654.

[19] L.B. Bangs, Pure Appl. Chem. 68 (1996) 1873-1879.

[20] T. Sano, C.L. Smith, C.R. Cantor, Science 258 (1992) 120-122.

[21] M. Adler, R. Wacker, C.M. Niemeyer, Biochem. Biophys. Res. Commun. 308 (2003) 240-250.

[22] Q. Zhang, L.-H. Guo, Bioconjugate Chem. 18 (2007) 1668-1672.

[23] A.L. Benvin, Y. Creeger, G.W. Fisher, B. Ballou, A.S. Waggoner, B.A. Armitage, J. Am. Chem. Soc. 129 (2007) 2025-2034.

[24] C.M. Niemeyer, M. Adler, R. Wacker, Trends Biotechnol. 23 (2005) 208-216. 